\title{
The efficacy of an education-based secondary outpatient prevention programme after acute coronary syndrome hospitalisations and treatment in Poland. The Patient Club initiative
} \author{
Nina Kudelko-Blacha ${ }^{3}$, Patrycja Koźmińska ${ }^{11}$, Małgorzata Oleksy ${ }^{12}$, Dariusz Dudek ${ }^{1}$ \\ 'Department of Interventional Cardiology, University Hospital, Krakow, Poland \\ ${ }^{2}$ Krakow Cardiovascular Research Institute Ltd, Krakow, Poland \\ ${ }^{3}$ Department of Interventional Cardiology, Intercard, Pinczow, Poland \\ ${ }^{4}$ Cardiovascular Centre Foundation, Krakow, Poland \\ ${ }^{5}$ Department of Interventional Cardiology, GVM Carint, Sanok, Poland \\ ${ }^{6}$ Department of Interventional Cardiology, Intercard, Krosno, Poland \\ 7Department of Interventional Cardiology, Intercard, Nowy Targ, Poland \\ ${ }^{8}$ Department of Interventional Cardiology, GVM Carint, Oswiecim, Poland \\ 'Department of Interventional Cardiology, Radomsko, Poland \\ ${ }^{10}$ Department of Interventional Cardiology, GVM Carint, Ostrowiec Swietokrzyski, Poland \\ ${ }^{11}$ Department of Interventional Cardiology, Carint-Scanmed, Krakow, Poland \\ ${ }^{12}$ Department of Interventional Cardiology, Intercard, Nowy Sacz, Poland
}

Zbigniew Siudak ${ }^{1}$, Michał Pers ${ }^{1}$, Karolina Dusza², Iwona Franczak ${ }^{3}$, Agata Zegzda4 ${ }^{4}$, Monika Bechta ${ }^{5}$, Anna Kwiatkowska ${ }^{6}$, Anna Knutelska ${ }^{7}$, Bernardyna Zemla ${ }^{8}$, Agnieszka Kubiak ${ }^{9}$, Mirosława Zarzycka ${ }^{10}$,

\section{A bstract}

Background: Guidelines on cardiovascular prevention from the European Society of Cardiology advocate sustained educational measures to be undertaken by both doctors and nurses to ensure lifestyle changes for patients after acute coronary syndromes (ACS). A planned programme of a series of educational meetings for patients after ACS was initiated in form of the Patient Club. Aim: To assess the efficacy of the Patient Club initiative in terms of increased knowledge on cardiovascular risk factors as well as utilisation of healthy lifestyle in patents who attend the programme.

Methods: Patients in nine cardiology centres in Poland, who were treated for ACS between October and December 2014, were included. A dedicated questionnaire on healthy lifestyle and knowledge on cardiovascular risk factors was filled in by patients at hospital discharge. In January 2015 the same questionnaire was filled in by the same group of patients before their local Patient Club meeting.

Results: There were 1273 patients hospitalised for ACS who were invited to join the Patient Club initiative. Of them, 372 (29\%) filled in the questionnaire both at discharge and at the Patient Club meeting. The percentage of patients who smoked cigarettes decreased from $14 \%$ to $5 \%(p<0.001)$, and the number of those who had at least 30 min of physical activity daily increased from $50 \%$ to $58 \%$ ( $p=0.015)$.

Conclusions: Patients who attended Patient Club meetings usually four weeks after ACS showed significant benefit in terms of healthy lifestyle changes and more guideline-recommended management of cardiovascular risk factors.

Key words: secondary prevention, acute coronary syndrome, registry

\section{Address for correspondence:}

Zbigniew Siudak, MD, PhD, Department of Interventional Cardiology, University Hospital, ul. Kopernika 17, 31-501 Kraków, Poland, tel: +48 124247181 ,

fax: +48 1242471 84, e-mail: zbigniew.siudak@gmail.com

Received: 24.07.2015 Accepted: 15.10.2015 Available as AoP: 20.11.2015

Kardiologia Polska Copyright (c) Polskie Towarzystwo Kardiologiczne 2016 


\section{INTRODUCTION}

Guidelines on cardiovascular prevention from the European Society of Cardiology strongly advocate sustained educational measures to be undertaken by doctors and nurses to ensure lifestyle changes for patients after acute coronary syndromes (ACS) in order to reduce cardiovascular risk burden [1]. At the same time, the authors of the guidelines noticed that non-governmental organisations (NGO) are important partners for healthcare providers in a joint effort to promote prevention programmes. The Polish model of optimal and comprehensive rehabilitation and prevention in cardiovascular diseases (CVD) was issued in 2013 [2]. According to this statement the education programme should be started immediately after early rehabilitation, and the patient's first ambulatory control visit should be performed four weeks after ACS. In the meantime, alarming data have been published for Poland, which suggest only modest improvement in the implementation of secondary prevention guidelines in everyday clinical practice for CVD as well as substantial long-term mortality for patients after myocardial infarction [3, 4]. Based on these recommendations and worrisome results of poor adherence to secondary prevention measures, a planned programme of a series of educational meetings for patients after ACS was initiated in the form of the Patient Club in nine invasive cardiology centres in Southern and Eastern Poland by the local NGO (Cardiovascular Centre Foundation, Krakow, Poland) independently from rehabilitation schemes that were applied by default. Previous studies have shown that patient education in the form of patient meetings in groups in a combination with a rehabilitation programme is an effective way to maintain regular physical activity and be a part of successful therapeutic education [5, 6] However, there are also studies that have discarded the role of educational materials handed out to patients, and an increased role of face-to-face interaction has been underlined [7, 8].

The aim of this registry study was to assess the efficacy of the voluntary Patient Club initiative as a part of a rehabilitation and prevention programme for patients after ACS in terms of attendance by patients, increased knowledge on cardiovascular risk factors, as well as utilisation of healthy diet, recommended time devoted to physical activity, and compliance to prescribed pharmacotherapy.

\section{METHODS}

The Cardiovascular Centre Foundation (Krakow, Poland) initiated the Patient Club educational programme (for secondary prevention) as part of standard of care in nine cooperating invasive cardiology centres (Krakow, Nowy Sacz, Nowy Targ, Oswiecim, Ostrowiec Swietokrzyski, Pinczow, Radomsko, Sanok, Krosno). Each patient in these centres, who underwent invasive coronary procedure, received during their hospital stay an educational kit, which included: printed materials on secondary prevention measures and smoking cessation, access to two educational websites (www.klub-pacjenta.pl and www.sercebezdymu.pl), and an invitation to a Patient Club meeting at each local centre, which would take place usually within 1-2 months (most often four weeks) from index hospitalisation in accordance with Polish recommendations [2]. Each patient was advised on smoking cessation and lifestyle changes required for better adherence to secondary prevention measures by trained nurses at hospital discharge in each centre. During Patient Club meetings lectures were held on "Life after myocardial infarction", "Proper diet", "Physical activity", and "Smoking cessation" by cardiologists and nurses. There were also cardiopulmonary resuscitation trainings provided by certified paramedics cooperating with the Foundation. Club meetings usually last ca. 2-3 h and are always free of charge since they have become a part of standard of care for the prevention programme in these hospitals.

For the purpose of this study, we included patients in nine invasive cardiology centres, who were treated for ACS in between October and December 2014. A dedicated questionnaire with 20 closed-ended questions on healthy lifestyle and knowledge on cardiovascular risk factors was filled in by patients at hospital discharge after nurse advice and an invitation to the Patient Club. In January 2015 the same questionnaire was filled in by the same group of patients at their local Patient Club meeting. Only patients who filled in both questionnaires were included in the analysis. Attendance at the Patient Club meeting was voluntary. Patients were invited during hospital discharge, and mail and phone invitations were repeated before the planned meeting in each centre. A subgroup analysis was performed, and patients were stratified by sex (males vs. females) and by age (young vs. old). The cut-off point for age groups was defined as 65 years of age.

This was a registry study that analysed data gathered routinely in these centres as part of the standard of care and complied according to the Declaration of Helsinki (with later amendments), and patients provided additional informed consent for data analysis.

\section{Statistical analysis}

Data were analysed according to statistical standards. Categorical variables were presented as percentages (\%) and continuous variables as means (with standard deviation). The independence of two categorical variables was determined by the Pearson $\chi^{2}$ test or in the case of small counts by the Fisher exact test. No correction for multiple testing was applied. A p value of less than 0.05 was considered to be statistically significant. All data processing and statistical calculations were performed using Statistica 10.0 software (Statsoft, Tulsa, OK, USA).

\section{RESULTS}

There were 1273 patients hospitalised for ACS in the nine participating invasive cardiology centres during October-December 2014, who were invited to join Patient Club initiative. Of these 372 (29\%) filled in the questionnaire both at dis- 
Table 1a. Dietary habits and modes of cooking and preparing food by patients

\begin{tabular}{|lccc|} 
& $\begin{array}{c}\text { Baseline approach status } \\
\text { (at hospital discharge) }\end{array}$ & $\begin{array}{c}\text { Follow up at Patient } \\
\text { Club meetings }\end{array}$ \\
\hline Use of high-fat products (e.g. milk, cheese) & $36 \%$ & $25 \%$ & $<0.001$ \\
Use of vegetables and fruit & $69 \%$ & $72 \%$ & $<0.001$ \\
Frying in oil & $28 \%$ & $16 \%$ & $<0.001$ \\
Steam cooking & $56 \%$ & $68 \%$ & $<0.001$ \\
Salting for taste & $35 \%$ & $26 \%$ & 0.006 \\
Using herbs for taste & $42 \%$ & $48 \%$ & 0.019 \\
\hline
\end{tabular}

Table $1 \mathrm{~b}$. Dietary habits and modes of cooking and preparing food by patients according to age groups

\begin{tabular}{|c|c|c|c|c|}
\hline & & $\begin{array}{l}\text { Baseline approach status } \\
\text { (at hospital discharge) }\end{array}$ & $\begin{array}{l}\text { Follow up at Patient } \\
\text { Club meetings }\end{array}$ & p \\
\hline \multirow[t]{2}{*}{ Use of high-fat products (e.g. milk, cheese) } & Young & $43 \%$ & $26 \%$ & 0.02 \\
\hline & Old & $30 \%$ & $23 \%$ & $<0.001$ \\
\hline \multirow[t]{2}{*}{ Use of vegetables and fruit } & Young & $59 \%$ & $71 \%$ & 0.155 \\
\hline & Old & $76 \%$ & $72 \%$ & $<0.001$ \\
\hline \multirow[t]{2}{*}{ Frying in oil } & Young & $33 \%$ & $15 \%$ & 0.02 \\
\hline & Old & $17 \%$ & $15 \%$ & 0.014 \\
\hline \multirow[t]{2}{*}{ Steam cooking } & Young & $45 \%$ & $68 \%$ & 0.005 \\
\hline & Old & $61 \%$ & $72 \%$ & 0.01 \\
\hline \multirow[t]{2}{*}{ Salting for taste } & Young & $38 \%$ & $22 \%$ & 0.02 \\
\hline & Old & $31 \%$ & $30 \%$ & 0.236 \\
\hline \multirow[t]{2}{*}{ Using herbs for taste } & Young & $43 \%$ & $43 \%$ & 0.956 \\
\hline & Old & $40 \%$ & $48 \%$ & 0.09 \\
\hline
\end{tabular}

Table 1c. Dietary habits and modes of cooking and preparing food by patients according to sex

\begin{tabular}{|llccc|} 
& & Baseline approach status & Follow up at Patient \\
(at hospital discharge) & Club meetings & P \\
Use of high-fat products (e.g. milk, cheese) & Women & $35 \%$ & $25 \%$ & 0.016 \\
& Men & $39 \%$ & $22 \%$ & 0.014 \\
Use of vegetables and fruit & Women & $71 \%$ & $72 \%$ & 0.06 \\
& Men & $64 \%$ & $75 \%$ & 0.025 \\
Frying in oil & Women & $33 \%$ & $15 \%$ & 0.029 \\
Steam cooking & Men & $29 \%$ & $16 \%$ & 0.005 \\
& Women & $47 \%$ & $60 \%$ & 0.159 \\
Salting for taste & Men & $55 \%$ & $75 \%$ & $<0.001$ \\
Using herbs for taste & Women & $35 \%$ & $30 \%$ & 0.715 \\
& Men & $37 \%$ & $29 \%$ & 0.058 \\
& Women & $37 \%$ & $50 \%$ & 0.214 \\
\hline
\end{tabular}

charge and while attending a Patient Club meeting in January 2015. The main reason for absence from the Patient Club meeting was: no time to attend the meeting (25\%), no means of transport to get to the meeting place (15\%), and still fragile condition after hospital discharge (10\%). The mean age in this group was $64.2 \pm 9.9$ years and $33 \%$ were women. Changes in dietary and cooking habits are presented in Table 1a, management of modifiable risk factors in Table 2a, and knowledge 
Table 2a. Risk factor management by patients

\begin{tabular}{|lccc|} 
& $\begin{array}{c}\text { Baseline approach status } \\
\text { (at hospital discharge) }\end{array}$ & $\begin{array}{c}\text { Follow up at Patient } \\
\text { Club meetings }\end{array}$ & P \\
\hline I smoke cigarettes regularly & $14 \%$ & $5 \%$ & $<0.001$ \\
I have $>$ 30 min of physical activity daily & $50 \%$ & $58 \%$ & 0.015 \\
I ride a bike regularly & $22 \%$ & $30 \%$ & 0.005 \\
I never stop taking medicines without the doctor's advice & $76 \%$ & $79 \%$ & 0.208 \\
\hline
\end{tabular}

Table 2b. Risk factor management by patients according to age group

\begin{tabular}{|c|c|c|c|c|}
\hline & & $\begin{array}{l}\text { Baseline approach status } \\
\text { (at hospital discharge) }\end{array}$ & $\begin{array}{l}\text { Follow up at Patient } \\
\text { Club meetings }\end{array}$ & $\mathbf{P}$ \\
\hline \multirow[t]{2}{*}{ I smoke cigarettes regularly } & Young & $24 \%$ & $6 \%$ & 0.004 \\
\hline & Old & $6 \%$ & $2 \%$ & 0.003 \\
\hline \multirow[t]{2}{*}{ I have $>30$ min of physical activity daily } & Young & $46 \%$ & $58 \%$ & 0.212 \\
\hline & Old & $53 \%$ & $61 \%$ & 0.04 \\
\hline \multirow[t]{2}{*}{ I ride a bike regularly } & Young & $24 \%$ & $32 \%$ & 0.149 \\
\hline & Old & $20 \%$ & $28 \%$ & 0.01 \\
\hline \multirow{2}{*}{$\begin{array}{l}\text { I never stop taking medicines without } \\
\text { the doctor's advice }\end{array}$} & Young & $73 \%$ & $88 \%$ & 0.03 \\
\hline & Old & $80 \%$ & $74 \%$ & 0.052 \\
\hline
\end{tabular}

Table 2c. Risk factor management by patients according to sex

\begin{tabular}{|c|c|c|c|c|}
\hline & & $\begin{array}{c}\text { Baseline approach status } \\
\text { (at hospital discharge) }\end{array}$ & $\begin{array}{l}\text { Follow up at Patient } \\
\text { Club meetings }\end{array}$ & $\mathbf{P}$ \\
\hline \multirow[t]{2}{*}{ I smoke cigarettes regularly } & Women & $8 \%$ & $6 \%$ & 0.01 \\
\hline & Men & $19 \%$ & $2 \%$ & 0.001 \\
\hline \multirow[t]{2}{*}{ I have $>30$ min of physical activity daily } & Women & $48 \%$ & $55 \%$ & 0.294 \\
\hline & Men & $51 \%$ & $64 \%$ & 0.048 \\
\hline \multirow[t]{2}{*}{ I ride a bike regularly } & Women & $15 \%$ & $30 \%$ & 0.01 \\
\hline & Men & $27 \%$ & $28 \%$ & 0.968 \\
\hline \multirow{2}{*}{$\begin{array}{l}\text { I never stop taking medicines without } \\
\text { the doctor's advice }\end{array}$} & Women & $75 \%$ & $78 \%$ & 0.04 \\
\hline & Men & $77 \%$ & $82 \%$ & 0.529 \\
\hline
\end{tabular}

on CVD in Table 3a. Subgroup analysis by age and gender are presented in Table 1b, 1c, 2b, 2c, 3b, and 3c, respectively.

\section{DISCUSSION}

The Patient Club established by the Cardiovascular Centre Foundation (Krakow, Poland) in cooperation with cardiovascular hospital centres in southern Poland is, to our knowledge, only one of several secondary prevention initiatives that have provided data on its efficacy in Poland. The prevention programme dedicated for a pre-defined patient group (after ACS) consisted of both passive (printed educational materials, websites) and active face-to-face social interaction between patients during Patient Club meetings and professional advice given by trained nurses at discharge from hospital. This is in line with the results from previous studies that have shown success only if these prevention measures combine all of the above [5-8]. The main results of the Patient Club study have shown a significant benefit for patients in terms of healthy lifestyle changes and more guideline-recommended management of cardiovascular risk factors. One might of course argue that, even though statistically significant, the changes in absolute numbers and percentages were only moderate. It seems also that the prevention programme had no impact on the knowledge of CVD in patients; however, in terms of proper identification of lipid disorders, chest pain responsible for myocardial infarction, and recommendations on modifiable risk factors, it still exceeded $70 \%$ before and after the Patient Club meeting, which seems acceptable. Maybe 
Table 3a. Patients' knowledge about cardiovascular risk factors

\begin{tabular}{|c|c|c|c|}
\hline & $\begin{array}{c}\text { Baseline approach status } \\
\text { (at hospital discharge) }\end{array}$ & $\begin{array}{l}\text { Follow up at Patient } \\
\text { Club meetings }\end{array}$ & $\mathbf{P}$ \\
\hline Proper hypercholesterolaemia definition & $44 \%$ & $44 \%$ & 0.800 \\
\hline Identification of modifiable risk factors & $79 \%$ & $76 \%$ & 0.126 \\
\hline Proper description of chest pain during myocardial infarction & $71 \%$ & $72 \%$ & 0.047 \\
\hline Knowledge on recommended physical activity & $77 \%$ & $77 \%$ & 0.858 \\
\hline Proper high blood pressure definition & $24 \%$ & $24 \%$ & 0.985 \\
\hline
\end{tabular}

Table 3b. Patients' knowledge about cardiovascular risk factors according to age group

\begin{tabular}{|c|c|c|c|c|}
\hline & & $\begin{array}{l}\text { Baseline approach status } \\
\text { (at hospital discharge) }\end{array}$ & $\begin{array}{l}\text { Follow up at Patient } \\
\text { Club meetings }\end{array}$ & $\mathbf{P}$ \\
\hline \multirow[t]{2}{*}{ Proper hypercholesterolaemia definition } & Young & $42 \%$ & $43 \%$ & 0.552 \\
\hline & Old & $39 \%$ & $39 \%$ & 0.976 \\
\hline \multirow[t]{2}{*}{ Identification of modifiable risk factors } & Young & $83 \%$ & $89 \%$ & 0.365 \\
\hline & Old & $78 \%$ & $64 \%$ & 0.012 \\
\hline \multirow{2}{*}{$\begin{array}{l}\text { Proper description of chest pain during } \\
\text { myocardial infarction }\end{array}$} & Young & $73 \%$ & $79 \%$ & 0.505 \\
\hline & Old & $71 \%$ & $64 \%$ & 0.044 \\
\hline \multirow{2}{*}{$\begin{array}{l}\text { Knowledge on recommended physical } \\
\text { activity }\end{array}$} & Young & $77 \%$ & $83 \%$ & 0.550 \\
\hline & Old & $79 \%$ & $70 \%$ & 0.121 \\
\hline \multirow[t]{2}{*}{ Proper high blood pressure definition } & Young & $23 \%$ & $28 \%$ & 0.477 \\
\hline & Old & $27 \%$ & $19 \%$ & 0.117 \\
\hline
\end{tabular}

Table 3c. Patients' knowledge about cardiovascular risk factors according to sex

\begin{tabular}{|c|c|c|c|c|}
\hline & & $\begin{array}{l}\text { Baseline approach status } \\
\text { (at hospital discharge) }\end{array}$ & $\begin{array}{l}\text { Follow up at Patient } \\
\text { Club meetings }\end{array}$ & $\mathbf{P}$ \\
\hline \multirow[t]{2}{*}{ Proper hypercholesterolaemia definition } & Women & $37 \%$ & $42 \%$ & 0.797 \\
\hline & Men & $42 \%$ & $38 \%$ & 0.751 \\
\hline \multirow[t]{2}{*}{ Identification of modifiable risk factors } & Women & $82 \%$ & $68 \%$ & 0.110 \\
\hline & Men & $83 \%$ & $81 \%$ & 0.667 \\
\hline \multirow{2}{*}{$\begin{array}{l}\text { Proper description of chest pain during } \\
\text { myocardial infarction }\end{array}$} & Women & $76 \%$ & $68 \%$ & 0.08 \\
\hline & Men & $70 \%$ & $75 \%$ & 0.417 \\
\hline \multirow{2}{*}{$\begin{array}{l}\text { Knowledge on recommended physical } \\
\text { activity }\end{array}$} & Women & $81 \%$ & $73 \%$ & 0.297 \\
\hline & Men & $78 \%$ & $78 \%$ & 0.787 \\
\hline \multirow[t]{2}{*}{ Proper high blood pressure definition } & Women & $24 \%$ & $20 \%$ & 0.06 \\
\hline & Men & $24 \%$ & $25 \%$ & 0.702 \\
\hline
\end{tabular}

the reasonable explanation here is the fact that nurses and printed materials plus websites provided to patients focused entirely on diet, medications, and physical exercise rather than explaining definitions of elevated blood pressure or hyperlipidaemia. This might be an indication of the need to focus more on these issues in future Patient Club meetings for new patients. Nevertheless, the beneficial changes in lifestyle, such as dietary habits and ways of food preparation, are clearly visible and might translate into clinical benefit if sustained in long-term observation. When analysing subgroups of patients it seems that younger ones (less than 65 years old) are more prone to add salt to their meals less and would not stop taking medicines without physician's approval, but at the same time they did not increase physical activity to a minimum of 30 min daily when comparing baseline and follow-up declarations. Younger patients, although less likely to question their physicians recommendations, do not feel the necessity to increase physical activity. There were also some differences 
regarding gender. Men significantly changed their dietary habits in terms of more frequent steam cooking and less salt, but also significantly increased physical activity. It is also worth noticing that smoking cessation was more pronounced in men $(19 \%$ to $2 \%)$ than in women ( $8 \%$ to $6 \%)$.

The most striking finding, however, is the fact that only $29 \%$ of patients attended the Patient Club meeting, usually four weeks after ACS. Even if we take into consideration patients who die, are unable to attend due to comorbidities, or live in a different city and would find it hard to attend, still there are ca. $50 \%$ of patients who seem not to respond to the invitation for no clear reason. That is why the results of our study might be biased due to the fact that only patients aware of the disease and willing to change their lifestyle joined the Patient Club and were eventually included in the study. The authors also believe that the cause may be due to the fact that the Patient Club takes place too long after hospital discharge, when patients have already become less prone to education and changing their everyday bad habits. It may be that the educational meeting should be performed earlier, ca. one week after hospital discharge for index event [9].

The Patient Club initiative can feasibly be performed in most invasive cardiology centres in Poland. It generates minimal costs and is thus probably very cost-efficient in comparison to other programmes [10]. Only a nationwide performance could provide sufficient data, due to a larger sample size, on its effectiveness in terms of hard endpoints in longer observation.

\section{Limitations of the study}

The major limitation of the study is the lack of a control group for comparison of the efficacy of the new educational programme. This is due to the fact that the Patient Club has become the standard of care in nine participating centres to provide every consecutive ACS patient with an educational programme. The questionnaire used in this registry was self-developed and not validated in other groups of patients.

\section{CONCLUSIONS}

Less than $1 / 3$ of patients came back for voluntary, free-of-charge Patient Club educational meetings. The patients who attended the meetings, usually four weeks after ACS, showed significant benefit in terms of healthy lifestyle changes and more guideline-recommended management of cardiovascular risk factors. More studies are required on the optional timing and type of secondary prevention educational training for ACS patients.
Cardiovascular Centre Fundation, Krakow, Poland based on eductional grant from AstraZeneca.

Conflict of interest: none declared

\section{References}

1. Perk J, De Backer G, Gohlke H et al. European Association for Cardiovascular Prevention and Rehabilitation (EACPR); ESC Committee for Practice Guidelines (CPG). European Guidelines on cardiovascular disease prevention in clinical practice (version 2012). The Fifth Joint Task Force of the European Society of Cardiology and Other Societies on Cardiovascular Disease Prevention in Clinical Practice (constituted by representatives of nine societies and by invited experts). Eur Heart J, 2012; 33: 1635-1701.

2. Jankowski P, Niewada M, Bochenek A et al. [Optimal model of comprehensive rehabilitation and secondary prevention]. Kardiol Pol, 2013; 71: 995-1003. doi: 10.5603/KP.2013.0246.

3. Jankowski P, Czarnecka D, Lysek R et al. Secondary prevention in patients after hospitalisation due to coronary artery disease: what has changed since 2006? Kardiol Pol, 2014; 72: 355-362. doi: 10.5603/KP.a2013.0350.

4. Gierlotka M, Zdrojewski T, Wojtyniak B et al. Incidence, treatment, in-hospital mortality and one-year outcomes of acute myocardial infarction in Poland in 2009-2012: nationwide AMI-PL database. Kardiol Pol, 2015; 73: 142-158. doi: 10.5603/KP.a2014.0213.

5. Lambert-Kerzner A, Del Giacco EJ, Fahdi IE et al. Multifaceted Intervention to Improve Cardiac Medication Adherence and Secondary Prevention Measures (Medication) Study Investigators. Patient-centered adherence intervention after acute coronary syndrome hospitalization. Circ Cardiovasc Qual Outcomes, 2012; 5: 571-576.

6. Pavy B, Barbet R, Carré F et al. Working Group of Exercise Rehabilitation and Sport; Therapeutic Education Commission of the French Society of Cardiology. Therapeutic education in coronary heart disease: position paper from the Working Group of Exercise Rehabilitation and Sport (GERS) and the Therapeutic Education Commission of the French Society of Cardiology. Arch Cardiovasc Dis, 2013; 106: 680-689.

7. Shah BR, Bhattacharyya O, Yu CH et al. Effect of an educational toolkit on quality of care: a pragmatic cluster randomized trial. PLoS Med, 2014; 11: e1001588.

8. Esmaeili Vardanjani SA, Fanisaberi L, Alirezaee Shahraki F et al. The effect of face-to-face education and educational booklet on heart health indexes of the hospitalized patients with myocardial infarction. Nurs Res Pract, 2013; 2013: 675634. doi: 10.1155/2013/675634.

9. Dudek D, Siudak Z, Solheim S. New model of secondary cardiovascular prevention for patients after acute coronary syndromes in Poland with regard to Norwegian experiences. Kardiol Pol, 2016; 74: 101-103. doi: 10.5603/KP.a2015.0176.

10. Zannad F, Dallongeville J, Macfadyen RJ et al. ESC Working Group on CardioVascular Pharmacology and Drug Therapy. Prevention of cardiovascular disease guided by total risk estimations: challenges and opportunities for practical implementation: highlights of a CardioVascular Clinical Trialists (CVCT) Workshop of the ESC Working Group on CardioVascular Pharmacology and Drug Therapy. Eur J Prev Cardiol, 2012; 19: 1454-1464.

Cite this article as: Siudak Z, Pers M, Dusza K et al. The efficacy of an education-based secondary outpatient prevention programme after acute coronary syndrome hospitalisations and treatment in Poland. The Patient Club initiative. Kardiol Pol, 2016; 74: 185-191. doi: 10.5603/KP.a2015.0225 


\title{
Skuteczność opartego na edukacji programu prewencji wtórnej dla chorych hospitalizowanych z powodu ostrego zespołu wieńcowego w Polsce. Program Klubu Pacjenta
}

\author{
Zbigniew Siudak ${ }^{1}$, Michał Pers ${ }^{1}$, Karolina Dusza ${ }^{2}$, Iwona Franczak ${ }^{3}$, Agata Zegzda ${ }^{4}$, Monika Bechta ${ }^{5}$, \\ Anna Kwiatkowska ${ }^{6}$, Anna Knutelska ${ }^{7}$, Bernardyna Zemla ${ }^{8}$, Agnieszka Kubiak ${ }^{9}$, Mirosława Zarzycka ${ }^{10}$, \\ Nina Kudelko-Blacha ${ }^{3}$, Patrycja Koźmińska ${ }^{11}$, Małgorzata Oleksy ${ }^{12}$, Dariusz Dudek ${ }^{1}$ \\ ${ }^{1}$ Klinika Kardiologii Interwencyjnej, Instytut Kardiologii, Uniwersytet Jagielloński Collegium Medicum, Kraków \\ ${ }^{2}$ Krakow Cardiovascular Research Institute sp. z o.o., Kraków \\ ${ }^{3}$ Oddział Kardiologii, Intercard, Pinczów \\ ${ }^{4}$ Cardiovascular Center Foundation, Kraków \\ ${ }^{5}$ Oddział Kardiologii, GVM Carint, Sanok \\ ${ }^{6}$ Oddział Kardiologii, Intercard, Krosno \\ 7Oddział Kardiologii, Intercard, Nowy Targ \\ ${ }^{8}$ Oddział Kardiologii, GVM Carint, Oświęcim \\ ${ }^{9}$ Oddział Kardiologii, Radomsko \\ ${ }^{10}$ Oddział Kardiologii, GVM Carint, Ostrowiec Świętokrzyski \\ ${ }^{11}$ Centrum Kardiologii Inwazyjnej, Carint-Scanmed, Kraków \\ ${ }^{12}$ Oddział Kardiologii, Intercard, Nowy Sącz
}

\section{Streszczenie}

Wstęp: W wytycznych Europejskiego Towarzystwa Kardiologicznego zaleca się u pacjentów po przebytym ostrym zespole wieńcowym (OZW) edukację prozdrowotną prowadzoną przez lekarzy i pielęgniarki. Klub Pacjenta to zaplanowany prospektywnie program spotkań edukacyjnych chorych po OZW.

Cel: Celem niniejszego badania była ocena skuteczności programu prewencji wtórnej zainicjowanego w postaci Klubu Pacjenta. Metody: Pacjentów po OZW włączano do badania rejestrowego w październiku-grudniu 2014 r. w 9 współpracujących ośrodkach kardiologii inwazyjnej. Pacjenci wypełniali kwestionariusz dotyczący nawyków i stylu życia. W styczniu-lutym 2015 r. ten sam kwestionariusz został wypełniony przez chorych, którzy wzięli udział w programie lokalnych Klubów Pacjenta.

Wyniki: Do Klubu Pacjenta zaproszono 1273 pacjentów hospitalizowanych z powodu OZW. Kwestionariusz zarówno przy wypisywaniu, jak i w trakcie trwania programu wypełniło 372 (29\%) osób. Odsetek chorych palących tytoń zmalał z 14\% do 5\% ( $<<0,001$ ), a odsetek pacjentów, którzy deklarowali minimum 30 min aktywności ruchowej dziennie, zwiększył się z 50\% do $58 \%$ ( $p=0,015)$.

Wnioski: Zaobserwowano istotne zmiany w występowaniu czynników ryzyka i istotną poprawę stylu życia u pacjentów, którzy skorzystali z udziału w programie prewencji wtórnej Klubu Pacjenta 4-8 tygodni po wypisaniu ze szpitala z powodu OZW. Słowa kluczowe: prewencja wtórna, ostry zespół wieńcowy, rejestr 